JURNAL PENDIDIKAN, p-ISSN 2715-095X, e-ISSN 2686-5041

Volume 29, No.1, Maret 2020 (77-84)

Online: http://journal.univetbantara.ac.id/index.php/ JP

\title{
Penerapan Model Pembelajaran Kooperatif Tipe numbered Head Together Sebagai Upaya Meningkatkan Prestasi Belajar Ilmu Pengetahuan Sosial
}

\author{
Joko Budi Marsono
}

Guru SMP Negeri 2 Sukoharjo, Email: jokoobudii@gmail.com

\begin{abstract}
Abstrak: Penelitian ini bertujuan untuk meningkatkan prestasi belajar Ilmu Pengetahuan Sosial melalui model pembelajaran kooperatif tipe NHT pada siswa kelas VII G SMP Negeri 2 Sukoharjo semester I tahun pelajaran 2019/2020. Penelitian ini adalah Penelitian Tindakan Kelas yang dilakukan di kelas VII G SMP Negeri2 Sukoharjo semester I tahun pelajaran 2019/2020 yang berjumlah 32 siswa. Teknik pengumpulan data yang digunakan adalah tes, observasi, dan dokumentasi.Tahap-tahap analisis data dalam penelitian ini adalah pengumpulan data, reduksi data, penyajian data, dan penarikan kesimpulan. Indikator keberhasilan adalah nilai rata-rata tes siswa sekurang-kurangnya 80,0 dan banyak siswa dengan nilai di atas kriteria ketuntasan minimal yaitu 70,0 mencapai $\geq 85 \%$. Berdasarkan penelitian yang telah dilakukan, dapat disimpulkan bahwa penerapan model pembelajaran kooperatif tipe NHT dapat meningkatkan prestasi belajar Ilmu Pengetahuan Sosial siswa kelas VII G SMP Negeri 2 Sukoharjo. Sebelum tindakan/prasiklus, prestasi belajar siswa yang mencapai KKM 15 siswa atau $46,9 \%$, pada siklus I, 23 siawa atau $71,9 \%$ dan pada siklus II, 30 siswa atau $93,75 \%$. Nilai rata-rata kelas sebelum tindakan/prasiklus sebesar 68,5 setelah tindakan siklus I sebesar 71,9 dan setelah tindakan siklus II sebesar 82,1.
\end{abstract}

Kata-kata Kunci:Model pembelajaran kooperatif tipe NHT, prestasi belajar Ilmu Pengetahuan Sosial.

\section{Implementation Model of Cooperative Learning Type Numbered Head Together Is As an Effort to Improve Learning Achievement Social Sciences Subjects}

\author{
Joko Budi Marsono
}

The Teacher of SMP Negeri 2 Sukoharjo, Email: Jokoobudii@gmail.com

\begin{abstract}
This study aims to improve learning achievement Social sciences subjects through cooperative learning model type NHT in students of class VII G SMP Negeri 2 Sukoharjo first semester academic year 2019/2020.This research is a Classroom Action Research conducted in class VII G SMP Negeri 2 Sukoharjo first semester of academic year 2019/2020 with 32 students. Data collection techniques used are tests, observations, and documentation. The stages of data analysis in this study are data collection, data reduction, data presentation, and conclusion. The success indicator is the average score of the student's test at least 80.0 and many students with a value above the minimum mastery criteria of 70.0 reach $\geq 85 \%$.Based on the research that has been done, it can be concluded that the application of cooperative learning model type NHT can improve learning achievement social sciences subjects student of class VII G SMP Negeri 2 Sukoharjo. Before the action/pre cycle, student learning outcomes reaching KKM 15 students or 46,9\%, in cycle I, 23 students or $71,9 \%$ and in cycle II, 30 students or $93,75 \%$. The average value of the class before the action / pre cycle was 68.5 after the first cycle action was 76,7 and after the second cycle action was 82.1.
\end{abstract}

Keywords: Cooperative learning model type NHT, learning achievement social sciences 
subjects.

\section{Pendahuluan}

Pembelajaran Ilmu Pengetahuan Sosial dimaksudkan dapat membangun apresiasi dan kreativitas siswa serta menumbuhkembangkan daya pikir imaginatif yang serba bisa. Daya pikir imaginatif dapat diraih apabila seorang anak berada dalam ruang lingkup pendidikan yang berorientasi pada pengembangan aktualisasi dan bimbingan yang mengarah pada pola pikir yang berkembang. Dalam pembelajaran Ilmu Pengetahuan Sosial, kreativitas sangat diperlukan, karena pada dasarnya kreativitas merupakan faktor penunjang tercapainya keberhasilan dalam belajar segala bentuk seni, budaya serta keterampilan. Hal ini dapat dilakukan dengan berbagai pendekatan seperti Pendekatan Konstruktivistik, dimana seorang anak/siswa dituntut untuk mencari sesuatu hal dengan kecerdasan berpikirnya melalui informasi secara mandiri, sehingga pada akhirnya anak mampu mencari dan menemukan suatu kreativitas melalui informasi serta pengetahuan yang telah didapatnya. Adapun pengertian kreativitas menurut John Adair adalah daya pikir dan semangat yang memungkinkan seseorang untuk mengadakan sesuatu yang memiliki kegunaan, tatanan, keindahan, atau arti penting dari sesuatu yang kelihatannya tidak ada.Sedangkan menurut Conny R. Semiawan, kreativitas merupakan kemampuan untuk melakukan gagasan baru dan menerapkannya dalam pemecahan masalah. Kreativitas itu sendiri memiliki 2 komponen yaitu Aptitude (kecakapan) dan Non Aptitude (bukan kecakapan). Kreativitas bisa ditumbuhkan dalam proses pembelajaran. Dimana siswalah yang menjadi subyek dalam pembelajaran. Dialah pelaku kegiatan belajar. Agar siswa berperan sebagai pelaku dalam kegiatan belajar maka guru hendaknya merencanakan pembelajaran yang menarik. Sehingga kegiatan pembelajaran dapat diciptakan di sekolah dan akan menjadikan suasana pembelajaran yang tidak membosankan sehingga peserta didik mengikuti pembelajaran dengan bertanya, mempertanyakan, dan mengemukakan gagasan.

Pada umumnya guru masih menggunakan model pembelajaran konvensional sehingga pembelajaran menjadi satu arah. Hal itu menyebabkan siswa cenderung pasif dan kurang tertarik dengan materi yang diberikan sehingga banyak siswa yang tidak memperhatikan materi pembelajaran.Sebagian besar siswa lebih banyak mendengarkan, mencatat dan kurang aktif dalam kegiatan pembelajaran. Suasana belajar seperti inilah yang terjadi pada siswa kelas VII G SMP Negeri 2 Sukoharjo. Selama proses pembelajaran Ilmu Pengetahuan Sosialberlangsung, siswa Kelas VII G mengikuti pelajaran dengan baik, tetapi siswa kurang merespon materi yang diberikan oleh guru. Kondisi seperti ini berdampak pada rendahnya prestasi belajar siswa pada aspek pengetahuan. Sebagian besar siswa mengalami kesulitan belajar potensi sumber daya alam dan kemaritiman indonesia. Karena materi ini memang cukup sulit dan siswa cenderung malu bertanya kepada guru jika mengalami kesulitan dalam memahami atau menyelesaikan soal yang diberikan, akibatnya prestasi belajar siswa pada materi tersebut belum maksimal.Randahnya keaktifan para siswa dalam belajar menjadi petunjuk bahwa siswa mengalami kesulitan belajar. Sehingga perlu adanya variasi pembelajaran agar siswa tertarik dan aktif dalam proses belajar mengajar. Dari hasil tes materi potensi sumber daya alam dan kemaritiman indonesia, siswa kelas VII G Semester I SMP Negeri 2 Sukoharjo Tahun Pelajaran 2019/2020 prestasi belajar untuk mata pelajaran Ilmu Pengetahuan Sosial masih rendah. Diperoleh nilai ratarata kelas 68,5, sedangkan KKM (Kriteria Ketuntasan Minimun) adalah 70 dengan jumlah siswa yang tuntas belajar sebanyak 15 siswa $(46,9 \%)$. Terdapat beberapa model 
pembelajaran kooperatif yang dapat diterapkan, yaitu antara lain STAD (Student TeamArchievementDivisions), jigsaw, TAI (Team Accelerated Instruction), TGT (Teams-GamesTournaments), dan NHT (Numbered Heads Together).Pada penelitian ini akan dicoba pembelajaran kooperatif tipe NHT (Numbered Heads Together). Teknik ini memberikan kesempatan kepada siswa untuk saling membagikan ide-ide dan mempertimbangkan jawaban yang paling tepat, selain itu mendorong siswa untuk meningkatkan semangat kerja sama dan daya serap materi yang diberikan guru.

Penggunaan modelpembelajaran kooperatif NHT diharapkan menjadi sarana belajar yang menarik dan menyenangkan, sehingga akan meningkatkan prestasi belajar siswa. Namun, apakah benar tidaknya pembelajaran kooperatif tipe NHT dapat meningkatkan prestasi belajar siswa pada materi potensi sumber daya alam dan kemaritiman indonesia, maka perlu dilakukan penelitian. Belajar menurut Sugihartono, dkk (2007) merupakan suatu proses perubahan tingkah laku sebagai hasil interaksi individu dengan lingkungannya dalam memenuhi kebutuhan hidupnya. Menurut Sanjaya (2008) belajar adalah proses mental yang terjadi dalam diri seseorang, sehingga menyebabkan munculnya perubahan tingkah laku. Aktivitas mental itu terjadi karena adanya interaksi individu dengan lingkungan yang disadari. Menurut Dimyati dan Mudjiono (2009) belajar adalah proses melibatkan manusia secara orang per orang sebagai satu kesatuan organisme sehingga terjadi perubahan pada pengetahuan, keterampilan, dan sikap. Sedangkan menurut Slameto dalam Djamarah (2008), belajar adalah suatu proses usaha yang dilakukan individu untuk memperoleh suatu perubahan tingkah laku yang baru secara keseluruhan, sebagai hasil pengalaman individu itu sendiri dalam interaksi dengan lingkungannya. Merangkum dari pendapat-pendapat di atas, maka belajar merupakan suatu proses memperoleh pengetahuan dan pengalaman dalam wujud perubahan tingkah laku karena adanya interaksi individu dengan lingkungannya. Prestasi adalah hasil dari suatu kegiatan yang telah dikerjakan, diciptakan baik secara individual maupun kelompok (Hamdani, 2011). Sedangkan menurut Purwodarminto (dalam Hamdani, 2011) menyatakan bahwa prestasi belajar adalah hasil yang dicapai sebaik-baiknya menurut kemampuan anak pada waktu tertentu terhadap halhal yang dikerjakan atau dilakukan. Selain itu, Winkel (dalam Hamdani, 2011) mengemukakan bahwa prestasi belajar adalah merupakan bukti yang telah dicapai oleh seseorang.

Menurut Hamdani (2011) "Prestasi belajar adalah hasil dari pengukuran terhadap siswa yang meliputi faktor kognitif, afektif dan psikomotorik setelah mengikuti proses pembelajaran yang diukur dengan menggunakan instrumen tes atau instrumen yang relevan". Jadi prestasi belajar adalah hasil pengukuran dari penilaian usaha belajar yang dinyatakan dalam bentuk simbol, huruf maupun kalimat yang menceritakan hasil yang sudah dicapai oleh setiap anak pada periode tertentu. Menurut Huda (2011), penerapan pembelajaran kooperatif tipe NHT akan memberikan kesempatan kepada siswa untuk saling membagikan ide-ide dan mempertimbangkan jawaban yang paling tepat, meningkatkan semangat kerja sama siswa dan dapat digunakan untuk semua mata pelajaran dan tingkat kelas. Adapun prosedur dalam metode pembelajaran kooperatif tipe NHT, yaitu: (1) Siswa dibagi dalam kelompok-kelompok. Masing-masing siswa dalam kelompok diberi nomor; (2) Guru memberikan tugas/pertanyaan dan masing-masing kelompok mengerjakannya; (3) Kelompok berdiskusi untuk menemukan jawaban yang dianggap paling benar dan memastikan semua anggota kelompok mengetahui jawaban tersebut; (4) Guru memanggil salah satu nomor. Siswa dengan nomor yang dipanggil mempresentasikan jawaban hasil diskusi kelompoknya. Tujuan penelitian ini adalah untuk meningkatkan 
prestasi belajar Ilmu Pengetahuan Sosial melalui pembelajaran kooperatif tipe NHT pada siswa SMP Negeri 2 Sukoharjo kelas VII G Semester I tahun pelajaran 2019/2020.

\section{Metode Penelitian}

Penelitian ini adalah Penelitian Tindakan Kelas.Penelitian tindakan kelas merupakan suatu pencermatan terhadap kegiatan yang sengaja dimunculkan, dan terjadi dalam sebuah kelas (Arikunto, 2010: 130).Penelitian ini dilaksanakan di SMP Negeri 2 Sukoharjo.Tahap-tahap pelaksanaan kegiatan dilakukan selama kurang lebih enam bulan yaitu sejak bulan Juli sampai dengan Desember 2019.Peneliti sebagai guru SMP Negeri 2 Sukoharjo bertindak sebagai subjek yang melakukan tindakan kelas. Teman sejawat sesame guru mata pelajaran Ilmu Pengetahuan Sosial sebagai observer.Kepala Sekolah bertindak sebagai subjek yang membantu dalam perencanaan dan pengumpulan data. Subjek yang menerima tindakan adalah siswa kelas VII G SMP Negeri 2 Sukoharjo semester Itahun pelajaran2019/ 2020 sebanyak 32 siswa. Adapun langkah-langkah penelitian untuk setiap siklus pembelajaran adalah sebagai berikut:

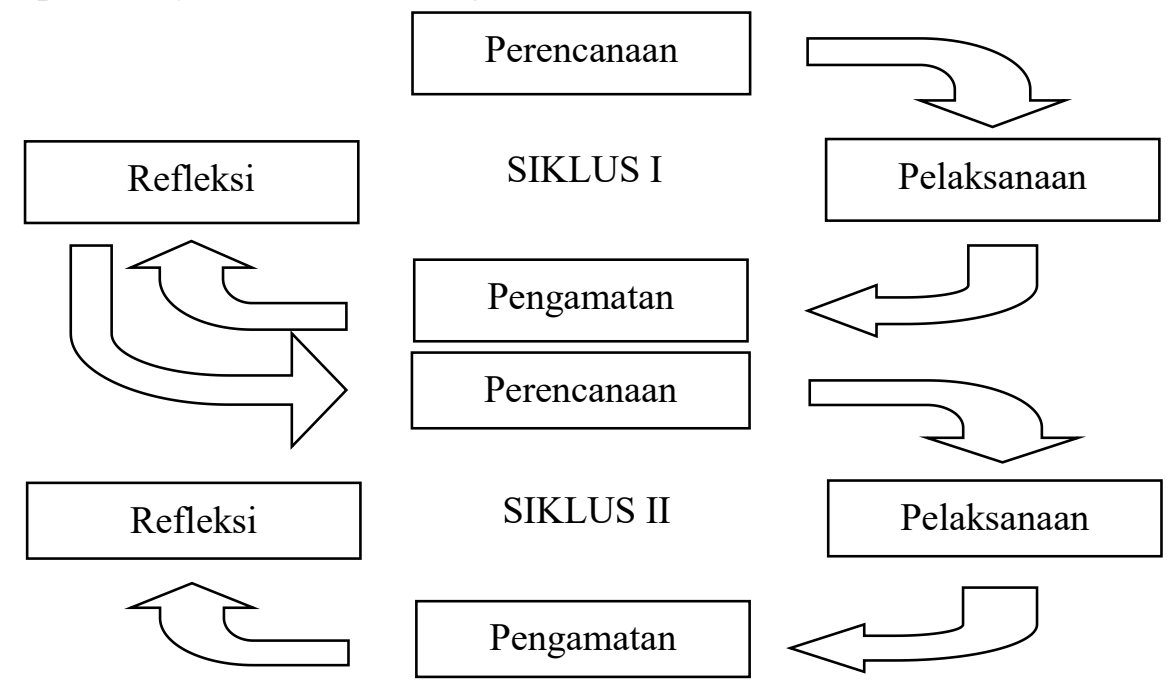

Gambar 1. Siklus Penelitian Tindakan (Arikunto, 2006)

Teknik pengumpulan data yang digunakan adalah: tes, observasi dan dokumentasi. Tes adalah serentetan pertanyaan atau latihan serta alat lain yang digunakan untuk mengukur keterampilan, pengetahuan inteligensi, kemampuan atau bakat yang dimiliki oleh individu dan kelompok (Arikunto, 2010: 193). Tes digunakan adalah jenis tes hasil(achievement test) berupa kuis individu.Tes ini digunakan untuk mengukur pencapaian siswa setelah mempelajari materi. Hal ini dapat juga sebagai alat untuk mengetahui tingkat pemahaman siswa setelah mempelajari pokok bahasan Potensi Sumber Daya Alam dan Kemaritiman Indonesia dengan menggunakan model pembelajaran kooperatif tipeNHT. Kuis individu yang dimaksudkan ini adalah tes tertulis. Tes tertulis adalah suatu teknik penilaian yang menunutut jawaban secara tertulis, baik berupa pilihan atau isian. Tes yang jawabannya berupa pilihan meliputi pilihan ganda, benar salah dan menjodohkan, sedangkan tes yang jawabannya berupa isian berbentuk isian singkat atau uraian (Suprijono, 2013).Observasi atau pengamatan dilakukan guna memperoleh data yang akurat, dengan menggunakan lembar observasi. Lembar observasi digunakan untuk memonitor dan 
mengevaluasi setiap tindakan agar kegiatan observasi tidak terlepas dari konteks permasalahan dan tujuan penelitian. Observasi yang digunakan adalah observasi sistematis, yaitu observasi yang dilakukan oleh pengamat dengan menggunakan pedoman sebagai instrumen pengamatan dan observasi non-sistematis yang dilakukan dengan tidak menggunakan instrumen pengamatan.Dokumentasi diperoleh dari hasil kuis siswa, lembar observasi, lembar wawancara, catatan lapangan, daftar siswa, dan foto-foto selama proses kegiatan belajar mengajar. Dokumentasi ini dimaksudkan adalah sebagai bukti-bukti konkret dari penelitian tindakan kelas tersebut. Instrumen yang digunakan dalam penelitian berupa tes, lembar observasi dan lembar dokumentasi. Tes berbentuk tes tertulis maupun lisan yang dilakukan dalam post test dan kuis individu. Tes ini digunakan untuk mengetahui sejauh mana peningkatan prestasi belajarPotensi Sumber Daya Alam dan Kemaritiman Indonesia siswa dengan penerapan model pembelajaran kooperatif tipe NHT. Lembar Observasi, digunakan lembar observasi prestasi belajar siswa dan lembar observasi pelaksanaan pembelajaran kooperatif. Lembar observasi digunakan pada setiap pembelajaran sehingga kegiatan observasi tidak terlepas dari konteks permasalahan dan tujuan penelitian, untuk lembar prestasi belajar siswa digunakan pada saat siswa dapat menyelesaikan permasalahan dengan kegiatan belajar mengajar dan sedangkan lembar observasi pelaksanaan kegiatan belajar mengajar dengan model pembelajaran Kooperatif TipeNHTdigunakan sebagai pedoman peneliti dalam melakukan observasi pelaksanaan kegiatan belajar mengajar dengan menggunakan model pembelajaran kooperatif tipe NHT. Lembar dokumentasi ini bertujuan untuk mengetahui data siswa selama kegiatan penelitian berlangsung.Lembar dokumentasi ini berupa, foto-foto kegiatan pembelajaran, daftar hadir kegiatan pembelajaran, daftar hadir, daftar nilai, kartu pasangan soal/jawaban dan sebagainya. Indikator keberhasilan kinerja dalam penelitian ini adalah meningkatnya prestasi belajarIlmu Pengetahuan Sosial materi Potensi Sumber Daya Alam dan Kemaritiman Indonesia siswa, yang ditunjukkan dengan meningkatnya nilai rata-rata tes siswa sekurang-kurangnya 80,0 dan banyak siswa dengan nilai di atas KKM yaitu $\geq 70,0$ mencapai $\geq 85 \%$.

\section{Hasil Penelitian}

Deskripsi data hasil penelitian yang telah dilakukan di kelas VII G SMP Negeri 2 Sukoharjo adalah sebagai berikut. Berdasarkan observasi awal di kelas VII G mata pelajaran ilmu pengetahuan sosial dengan materi potensi sumber daya alam dan kemaritiman indonesia diperoleh data, dari 32 siswa yang mencapai nilai KKM sebanyak 15 siswa (46,9\%), dengan nilai rata-rata kelas sebesar 68,5.Penelitian ini dilakukan dengan indikator kinerja nilai rata-rata tes siswa sekurang-kurangnya 80,0 dan banyak siswa dengan nilai di atas KKM yaitu $\geq 70,0$ mencapai $\geq 85 \%$. Hasil observasi awal menunjukkan bahwa guru yang mendominasi kegiatan pembelajaran dan siswa cenderung tidak aktif. Salah satu solusi yang dikembangkan adalah penggunaan model pembelajaran yang baru yaitu dengan Model Pembelajaran Kooperatif Tipe NHT. Dengan penggunaan model pembelajaran tersebut diharapkan akan menciptakan suasana belajar yang berbeda, bervariasi dan menyenangkan sehingga dapat menarik perhatian siswa, meningkatkan keaktifan siswa yang muara akhirnya meningkatkan prestasi belajar siswa. Berdasarkan hasil evaluasi pada siklus I menunjukkan adanya peningkatan prestasi belajar siswa. Prestasi belajar siswa sebanyak 23 mencapai nilai KKM atau 71,9\%, rata-rata kelas naik menjadi 76,7. Berdasarkan pengamatan tersebut dapat diketahui bahwa proses pembelajaran pada siklus pertama belum berhasil maksimal dan belum mencapai indikator 
kinerja yang diharapkan. Peningkatan hasil, jika dibandingkan hasil prasiklus yang mencapai KKM sebanyak 15 siswa atau 46,9\% setelah diberi tindakan penerapan siklus I, siswa yang mencapai KKM sebanyak 23 siswa atau $71,92 \%$.

Tabel 1.Perkembangan Siswa yang Mencapai KKM Sebelum Tindakan ke Siklus I

\begin{tabular}{rcc}
\hline Hasil Siswa & Prasiklus & Siklus I \\
\hline Siswa mencapai KKM & 15 & 23 \\
\hline
\end{tabular}

Dari tabel di atas dapat disimpulkan bahwa prestasi belajar ilmu pengetahuan sosial materi Potensi Sumber Daya Alam dan Kemaritiman Indonesia siswa dengan menerapkan model pembelajaran kooperatif tipe NHT, pada pelaksanaan tindakan siklus I mengalami peningkatan. Siswa yang mencapai KKM Sebelum dilakukan tindakan atau prasiklus 15 siswa, setelah tindakan siklus I sebanyak 23 siswa sehingga meningkat 8 siswa. Setelah dievaluasi bersama dari pelaksanaan tindakan pada siklus I yang digunakan sebagai bagian pertimbangan perencanaan pembelajaran siklus berikutnya, dengan perencanaan perbaikan untuk mengatasi kekurangan dan kesalahan yang dilakukan pada siklus I. Berdasarkan pembelajaran secara keseluruhan pada tindakan kelas siklus II menunjukan adanya peningkatan yang signifikan. Prestasi belajar siswa sebanyak 30 siswa $(93,75 \%)$ mencapai nilai KKM. Sehingga rata-rata nilai kelas VII G naik menjadi 82,1.

Tabel 2. Perkembangan Siswa yang Mencapai KKM Siklus I ke Siklus II

\begin{tabular}{ccc}
\hline Hasil Siswa & Siklus I & Siklus II \\
Siswa mencapai KKM & 23 & 30
\end{tabular}

Dari tabel di atas dapat disimpulkan bahwa prestasi belajar Potensi Sumber Daya Alam dan Kemaritiman Indonesia siswa dengan menerapkan model pembelajaran kooperatif tipe NHT, pada pelaksanaan tindakan siklus II mengalami peningkatan. Siswa yang mencapai KKM pada saat dilakukan tindakan siklus I sebanyak 23 siswa, setelah tidakan siklus II sebanyak 30 siswa sehingga meningkat 7 siswa. Berdasarkan hasil tersebut dapat diketahui bahwa proses pembelajaran sampai dengan pada siklus II berjalan dengan baik dan telah memenuhi indikator kinerja yang diharapkan.

\section{Pembahasan}

Pada siklus I dan II dengan penerapan tindakan menggunakan model pembelajaran kooperatiftipe NHT, sehingga siswa lebih antusias dengan perasaan senang dalam mengikuti kegiatan pembelajaran. Nilai rata-rata siswa sejak sebelum diadakan penelitian hingga setelah diadakan penenelitian sampai dengan siklus II, dapat dilihat pada tabel berikut:

Tabel 3.Perkembangan KKM Sebelum Tindakan, Siklus I dan Siklus II

\begin{tabular}{lccc}
\hline HasilSiswa & Prasiklus & Siklus I & Siklus II \\
\hline Siswa mencapai KKM & 15 & 23 & 30 \\
\hline
\end{tabular}

Dari tabel di atas dapat disimpulkan bahwa prestasi belajar materi Potensi Sumber Daya Alam dan Kemaritiman Indonesia siswa dengan menerapkan model pembelajaran kooperatif tipe NHT, di setiap pelaksanaan tindakan, baik siklus I dan siklus II mengalami peningkatan, yaitu: siswa yang mencapai KKM Sebelum dilakukan tindakan atau prasiklus 15 siswa, setelah tidakan siklus I sebanyak 23 siswa dan setelah tindakan siklus II sebanya 30 siswa, sehingga peningkatan kumulatif dari sebelum tindakan/prasiklus sampai dengan siklus II sebesar 10 siswa.

Tabel 4.Perkembangan KKM Sebelum Tindakan/Prasiklus, Siklus I dan Siklus II 


\begin{tabular}{lrrc}
\hline Hasil Siswa & Prasiklus & \multicolumn{1}{c}{ Siklus I } & Siklus II \\
\hline Persentase Siswa & $46,9 \%$ & $71,9 \%$ & $93,75 \%$ \\
Mencapai KKM & & & \\
\hline
\end{tabular}

Dari tabel di atas dapat disimpulkan bahwa prestasi belajar materi Potensi Sumber Daya Alam dan Kemaritiman Indonesia siswa dengan menerapkan model pembelajaran kooperatif tipe NHT, di setiap pelaksanaan tindakan mengalami peningkatan, yaitu: presentase siswa yang mencapai KKM Sebelum dilakukan tindakan atau prasiklus 46,9\%, setelah tidakan siklus I sebanyak 71,9\% dan setelah tindakan siklus II sebanya 93,75\%.

Tabel 5. Perkembangan Nilai Rata-rata Kelas Sebelum Tindakan, Siklus I dan Siklus II

$\begin{array}{clll}\text { Hasil Siswa } & \text { Prasiklus } & \text { Siklus I } & \text { Siklus II } \\ \text { Nilai rata-rata } & 68,5 & 76,7 & 82,1\end{array}$

Dari tabel di atas dapat disimpulkan bahwa prestasi belajar prakarya materi Potensi Sumber daya Alam dan Kemaritiman Indonesia siswa dengan menerapkan model pembelajaran kooperatif tipe NHT, di setiap pelaksanaan tindakan mengalami peningkatan, yaitu: nilai rata-rata kelas sebelum dilakukan tindakan atau prasiklus adalah 68,5 , setelah tidakan siklus I adalah 76,7 dan setelah tindakan siklus II adalah 82,1 sehingga dari kondisi awal sebelum tindakan/prasiklus sampai dengan tidakan pada siklus II terjadi peningkatan. Dari uraian di atas dapat disimpulkan bahwa model pembelajaran kooperatif tipe NHT dapat meningkatkan prestasi belajar prakarya materi Potensi Sumber Daya Alam dan Kemaritiman Indonesia siswa kelas VII G SMP Negeri 2 Sukoharjo semester I tahun pelajaran 2019/ 2020.

\section{Simpulan dan Saran}

Berdasarkan hasil penelitian dapat disimpulkan, dengan penerapan model pembelajaran kooperatif tipe NHT dapat meningkatkan prestasi belajar ilmu pengetahuan sosial pada siswa kelas VII G SMP Negeri 2 Sukoharjo semester I tahun pelajaran 2019/2020. Penelitian Tindakan Kelas yang dilaksanakan di SMP Negeri 2 Sukoharjo ini sudah berjalan dengan cukup baik dan hasil yang baik pula. Namun masih banyak hal yang perlu diperbaiki. Oleh karena itu, peneliti memberikan beberapa saran. (1) Siswa diharapkan dapat lebih meningkatkan kemampuan diri melalui peran aktifnya dalam mengikuti kegiatan belajar mengajar. Peran aktif tersebut meliputi peran aktif dalam bertanya, mengemukakan pendapat maupun mempresentasikan gagasannya. (2) Guru ilmu pengetahuan sosial hendaknya dapat menumbuh kembangkan kreativitas dalam menjalankan profesinya sebagai fasilitator dan motivator dalam menyampaikan pembelajaran secara kreaktif dan inovatif pada siswa dalam penyampaian materi, sehingga siswa dapat menerima dan memahami materi yang diajarkan dengan baik. (3) Penelitian Tindakan Kelas ini diharapkan akan membawa dampak positif terhadap perkembangan sekolah yang nampak pada peningkatan prestasi belajar siswa sehingga dapat meningkatkan prestasi dan kualitas sekolah.

\section{Daftar Rujukan}

Arikunto, A. (2006). Prosedur Penelitian Suatu Pendekatan Praktik. Jakarta: Rineka Cipta. Dimyati dan Mudjiono. (2009). Belajar dan Pembelajaran. Jakarta: Rineka Cipta.

Djamarah, S. B. (2008). Psikologi Belajar. Jakarta: Rineka Cipta. 
Huda, M. (2011). Coopertive Learning Metode, Teknik, Struktur dan Model Penerapan. Yogyakarta: Putaka Pelajar.

Isjoni. (2011). Cooperative Learning Efektifitas Pembelajaran Kelompok. Bandung: Alfabeta.

Sanjaya, W. (2008). Stretegi Pembelajaran Berorientasi Standar Proses Pendidikan. Jakarta: Kencana.

. (2009). Perencanaan dan Desain Sistem Pembelajaran. Jakarta: Kencana.

Sugihartono, dkk. (2007). Psikologi Pendidikan. Yogyakarta: UNY Press.

Sujatmiko, P. (2005). Seni musikKreatif 2. Solo: Tiga Serangkai Pustaka mandiri

Taniredja, T, Irma, dan Nyata. (2010). Penelitian Tindakan Kelas Untuk Pengembangan Profesi Guru Praktik, Praktis, dan Mudah. Bandung: Alfabeta.

Untoro, J. (2007). Buku Pintar Seni musikSMP. Jakarta: WahyuMedia. 